\title{
ANALISIS FAKTOR YANG MEMPENGARUHI KEJADIAN POST PARTUM BLUES
}

\author{
${ }^{1)}$ Sandra Harianis, ${ }^{2)}$ Nurul Indah Sari \\ Prodi D-III Kebidanan, STIKes Husada Gemilang \\ Jl. Pendidikan Tembilahan - Inhil - Riau - Indonesia \\ E-mail : ${ }^{1)}$ nda_harianis@yahoo.co.id ${ }^{2)}$ nurulindahsari4188@gmail.com
}

Kata Kunci:

Postpartum blues, faktor resiko, angka kejadian
Keywords:

Postpartum blues, risk factors, incidence rate

\section{Info Artikel}

Tanggal dikirim: 15-10-2021

Tanggal direvisi: 20-11-2021

Tanggal diterima: 23-1-2022

DOI Artikel:

10.36341/jomis.v6i1.2141

Creative Commons Attribution-

NonCommercial-ShareAlike 4.0 International License.

\begin{abstract}
ABSTRAK
Depresi adalah gangguan umum pada wanita usia subur. Gejala postpartum blues mulai dari ringan hingga gangguan mood yang signifikan seperti depresi postpartum dan psikosis postpartum. Postpartum blues sangat umum, mempengaruhi 30-75\% ibu baru. Banyak faktor yang berpengaruh terhadap kejadian ini baik internal maupun eksternal. Penelitian ini untuk mengetahui apakah faktor pendidikan kesehatan keterlibatan keluarga, perencanaan kehamilan, dan komplikasi persalinan berpengaruh dengan kejadian postpartum blues. Desain penelitian deskriptif analitik dengan pendekatan cross sectional. Sampel dalam penelitian ini sebanyak 73 orang dengan menggunakan alat skrining Edinnburg Postnatal Depression Scale (EPDS). Penelitian dilakukan di Puskesmas Tembilahan Hulu dan Puskesmas Gajah Mada pada bulan Maret-April 2021. Pengumpulan data menggunakan instrument test dan lembar observasi. Uji statistik Chi Square untuk melihat korelasi antar variabel. Hasil analisis didapatkan adanya korelasi antara pendidikan kesehatan setelah persalinan yang diberikan tenaga kesehatan ( $\mathrm{p}=0,001$, CI 3,225 - 50,404, OR 12,750) dan keterlibatan keluarga dalam mengurus bayi $(\mathrm{p}=0,003$, CI 2,020 - 32,594, OR 8,114) dengan kejadian postpartum blues. Sedangkan rencana kehamilan $(p=0,736)$ dan komplikasi persalinan $(p=0,969)$ berdasarkan uji statistik tidak memiliki korelasi yang signifikan. Dibutuhkan dukungan sosial, informasi dan bantuan tenaga kesehatan bagi ibu yang mengalami postpartum blues dan dilakukan skrining postpartum blues sebelum ibu diperbolehkan pulang.untuk perawatan nifas dirumah.
\end{abstract}

\begin{abstract}
Depression is a common disorder in women of childbearing age. Symptoms of the postpartum blues range from mild to significant mood disorders such as postpartum depression and postpartum psychosis. The 'postpartum blues' are extremely common, affecting 30-75\% of new mothers. Many factors influence this incident both internally and externally. This study was to determine whether the factors of health education, family involvement, pregnancy planning, and delivery complications have an effect on the incidence of postpartum blues. This study used the observational approach with a cross-sectional design. Samples in this study were 73 people used screening instrument of Edinburg Postnatal Depression Scale (EPDS). This study was conducted in Tembilahan Hulu and Gajah Mada Public Health Center in March-April 2021. Data collection with instrument test and observation sheet. Statistical Chi-Square test (X2) to see the correlation between variables. The results of the analysis showed that there was a correlation between postnatal health education provided by health workers ( $p=0.001$, CI $3.225-50.404$, OR 12.750) and family involvement in taking care of the baby $(p=0.003, C I 2.020-32.594, O R$ $8.114)$ with the incidence of postpartum blues. Meanwhile, pregnancy plans $(p=0.736)$ and delivery complications $(p=0.969)$ based on statistical tests did not have a significant correlation. Social support, information and assistance from health workers are needed for mothers who experience the postpartum blues and screening for the postpartum blues is carried out before the mother is allowed to go home for postpartum care at home
\end{abstract}

\section{PENDAHULUAN}

Setiap perempuan menantikan proses melahirkan. Dimana peristiwa ini dapat membangun persepsi dimasyarakat bahwa seorang perempuan yang telah melahirkan adalah seorang perempuan yang sempurna. Masa kehamilan, persalinan dan nifas adalah suatu fase yang membutuhkan dukungan sosial baik dari pihak eksternal seperti lingkungan dan tenaga kesehatan maupun dari internal 
yaitu keluarga terdekat terutama suami. Pada masa nifas ibu akan mendapati beberapa perubahan pada tubuh maupun emosi [1]

Perubahan emosi yang dialami wanita selama masa post partum sekaligus menyesuaikan diri menjadi seorang ibu. Perubahan status hormonal secara signifikan pada masa nifas menyebabkan timbulnya perubahan mood, kecemasan, emosional tidak stabil, mudah menangis, letih bingung, atau pikiran kacau [2]. Perubahan psikologis ini dapat menjadi masalah psikologis ringan sampai berat yang menunjukkan gejala kearah depresi pasca melahirkan.

Postpartum blues adalah masalah psikologis pada masa setelah persalinan, dimana seorang perempuan merasakan sedih dan depresi segera. Gejala mulai muncul dua atau tiga hari setelah persalinan dan biasanya hilang dalam satu atau dua minggu (Gennaro dalam Bobak dkk, 2005). Postpartum blues dikategorikan sebagai sindroma gangguan psikologis ringan, akan tetapi apabila tidak mendapatkan penanganan yang tepat akan jatuh pada gangguang psikologis sedang sampai berat yaitu pada fase depresi postpartum dan postpartum psychosis. (Reck et al, 2009) [1]

Kurangnya penelitian tentang morbiditas psikologis di negara berkembang telah menyebabkan kesenjangan dalam menilai prevalensi kejadian secara umum. Oleh karena itu, prevalensi diperkirakan antara $10 \%$ dan $20 \%$, dengan rata-rata prevalensi $13 \%$. Ini ditentukan oleh letak geografis lokasi dan sosial-kondisi perekonomian [3].

Beberapa negara menunjukkan angka kejadian postpartum blues yang bervariasi. Asia merupakan negara yang juga mengalami kejadian postpartum blues cukup tinggi yaitu berkisar antara 26-85\% seperti di Jepang 1550\%. Sedangkan di Amerika Serikat 27\%, prancis $31,7 \%$, Nigeria $31,3 \%$ dan Yunani $44,5 \%$ [4].

Di Indonesia, wanita yang mengalami kejadian postpartum blues berkisar antara 50$70 \%$ [4]. Jika dilihat angka insiden postpartum bules di Indonesia yaitu 1 sampai 2 per 1000 kelahiran. Berdasarkan angka kejadian tersebut sekitar 50-60\% diantaranya mengalami depresi postpartum saat mereka memiliki anak pertama dan sekitar 50\% mempunyai riwayat keluarga gangguan mood (Wahyuni, 2016) [5]

Sebagian besar yang mengalami postpartum blues terdeteksi setelah kondisinya mengalami depresi berat (Postpartum psychosis). Postpartum psikosis yang mengakibatkan perubahan mood secara drastis dapat terajdi akibat dari depresi yang tidak tertangani dengan baik. Hal ini berpotensial memunculkan terjadinya tindakan yang dapat melukai diri seperti bunuh diri dan membunuh bayi yang baru dilahirkannnya.

Dampak depresi postpartum bukan kepada ibunya saja, akan tetapi terhadap anaknya juga. Ibu yang mengalami tekanan akibat postpartum blues akan sulit berinteraksi dengan anaknya, sehingga hal ini juga dapat meningkatkan resiko gangguan tingkah laku dan gangguan kognitif bahkan dapat membahayakan anak [5]. Untuk itu deteksi yang akurat dan pengobatan tekanan psikologis sangat diperlukan pada periode awal postpartum [6].

Penilaian status mental postpartum ibu dan adaptasi ibu adalah bagian dari perawatan klinis standar. Alat skrining depresi pascamelahirkan seperti Edinburgh Postpartum Depression Scale (EPDS) dapat digunakan sebagai salah satu upaya untuk mendiagnosis masalah kesehatan mental ibu dengan cepat sehingga dengan demikian dapa dibemberikan pengobatan yang tepat untuk meningkatkan kesejahteraan ibu dan bayi[7].

Faktor resiko terjadinya postpartum blues dapat berasal dari internal maupun eksternal. Faktor internal yang dapat menyebabkan postpartum blues yaitu perubahan hormonal yang fluktuatif setelah bersalin, faktor psikologis dan kepribadian, pernah mengalami depresi sebelumnya. Faktor internal lainnya juga didapat dari perempuan yang memiliki riwayat kehamilan dan persalinan dengan komplikasi, persalinan section caesarea, kehamilan yang tidak direncanakan, bayi berat badan lahir rendah (BBLR), dan pada ibu yang menyusui dan mengalami kesulitan dalam menyusui serta ibu yang tidak mempunyai pengalaman merawat bayi[7]. Sedangkan faktor dari luar disebabkan karena dukungan 
keluarga dan lingkungan yang kurang dan kondisi sosial ekonomi.

Oleh karena itu penelitian ini bertujuan untuk menganalisis faktor-faktor resiko dengan kejadian postpartum blues di puskesmas Tembilahan Hulu dan Puskesmas Gajah Mada Tembilahan. Dimana didapatkan data persalinan di dua Puskesmas ini adalah jumlah persalinan terbanyak di kabupaten Indragiri Hilir. Sehingga memudahkan bagi peneliti untuk mendapatkan data dan responden.

\section{TINJAUAN PUSTAKA}

\section{Defenisi}

Postpartum adalah masa setelah persalinan dimana seorang perempuan akan mengalami banyak perubahan baik fisik maupun emosional. Perubahan emosional yang sangat intens mengarah pada gangguan kecemasan dan suasana hati. Gangguan emosional dan mood postpartum ini dapat dikategorikan menjadi tiga tingkatan yaitu postpartum blues (ringan), depresi postpartum (sedang), dan postpartum psychosis (berat). Postpartum blues merupakan perasaan sedih yang dialami oleh ibu melahirkan. Semua ibu postpartum memiliki resiko untuk terjadinya gangguan mood tanpa memandang etnik dan ras manapun, selain itu juga dapat terjadi pada ibu primipara maupun multipara [8].

Susanti (2018) menyebutkan bahwa postpartum blues merupakan suatu sindroma gangguan sikap yang ringan sering tampak dalam minggu pertama setelah persalinan, cenderung akan memburuk pada hari ketiga sampai kelima dan berlangsung dalam rentang waktu 14 hari atau dua minggu.

Hasil studi epidemiologi, waktu yang digunakan untuk menentukan masa keadian postpartum blues berkisar dari 3 bulan (Kendell et al., 1987) hingga 12 bulan setelah melahirkan (Miller, 2002). Sedangkan beberapa literatur lainnya mengatakan bahwa postpartum blues teradi pada minggu-minggu pertama hingga setahun setelah bayi lahir. Berdasarkan dari beberapa pernyataan diatas penulis menyimpulkan kejadian postpartum blues dapat diawali dari hari pertama kelahiran hingga bayi berusia satu tahun. Namun, kejadian tersering postpartum blues adalah pada minggu pertama dan kedua setelah persalinan.

Kejadian postpartum blues normalnya terjadi selama 2-3 hari. Sangat wajar jika seorang ibu yang baru melahirkan merasa lelah, cemas, dan kurang bersemangat dalam menjalani aktivitas sehari-hari [9]. Hal itu disebabkan oleh penurunan hormon serta perubahan kimia di dalam otak.

Apabila gejala perubahan psikologis semakin memburuk dan terajdi lebih dari seminggu, maka perubahan sikap ini dapat dikategorikan sebagai gangguan psikologis abnormal yang disebut depresi postpartum.

Sangat perlu diperhatikan perubahan sikap yang dialami ibu setelah melahirkan. Hal ini untuk memastikan agar semua masalah psikologis pascamelahirkan dimasukkan dalam studi penelitian untuk memberikan informasi yang akurat tentang aspek klinis dan diagnostik penyakit.

Penurunan minat dan ketertarikan terhadap bayi dapat dirasakan Ibu yang mengalami depresi postpartum. Ketidakmampuan dalam merawat bayinya secara optimal mengakibatkan ibu tidak bersemangat menyusui, sehingga kebersihan, kesehatan serta tumbuh kembang bayi menjadi tidak optimal. Depresi postpartum dan postpartum blues berhubungan erat, apabila postpartum blues tidak teratasi maka terjadilah depresi postpartum. Pada ibu yang mengalami depresi postpartum, kemungkinan besar akan mengalami masalah dalam proses bounding attachment, bayi tidak mendapat ASI dan munculnya penolakan dari orangtuanya.

Depresi adalah gangguan umum pada wanita usia subur. Banyak wanita mengalami gejala depresi selama periode postpartum, mulai dari postpartum blues ringan hingga gangguan mood yang signifikan seperti depresi postpartum dan psikosis postpartum [10].

\section{Penyebab}

Secara pasti, postpartum blues tidak diketahui penyebabnya. Diduga sebagian besar disebabkan oleh faktor internal seperti faktor 
klinis, faktor terkait obstetri dan bayi, atribusi kognisi dan neurotisisme, pengalaman sosial, status perkawinan dan hubungan perkawinan. Faktor eksternal hanya sebagian kecil yang dapat menyebabkan postpartum blues seperti dukungan suami, keluarga dan tenaga kesehatan serta pendapatan [11].

Tubuh akan mengalami banyak penyesuaian baik itu setelah melahirkan normal maupun operasi caesar. Pola makan berubah, dan terjadi pula perubahan fisik serta emosi yang dapat ikut terpengaruh. Ditambah adanya tekanan dari tanggung jawab besar terhadap bayi yang telah dilahirkan. Rutinitas sehari-hari dalam merawat bayi dapat menimbulkan kelelahan. Hal inilah yang memicu terjadinya postpartum blues [12].

Perencaan kehamilan merupakan suatu hal yang penting dalam mewujudkan keluarga berencana. Pada kenyataannya, banyak kelahiran tanpa direncanakan yang disebabkan oleh kegagalan dalam kontrasepsi, kehamilan diluar pernikahan. Ini merupakan salah satu faktor pemicu keajdian post partum blues. Dalam penelitiannya, Abbas (2010) menemukan bahwa teradap perbedaan yang signifikan antara kehamilan yang direncanakan $(12,3 \%)$ dengan tidak terencana $(87,7 \%)$ dengan keajdian depresi post partum [3].

\section{Masalah Klinis dan Diagnostik}

Gejala umum postpartum blues ditandai dengan, perasaan sedih atau disforia, labilitas perasaan, mudah tersinggung (irritable), mudah menangis (tearfulness), cemas, nyeri kepala (headache). Gejala ini dapat muncul sesaat setelah persalinan, beberapa hari sampai 2 minggu setelah persalinan. Apabila gejala tidak terdeteksi dan tidak tertangani maka gejala dapat berlanjut dalam beberapa minggu atau bulan. Kondisi ini lebih berat yang disebut depresi postpartum dan psikosis[7].

Dalam menentukan diagnosis depresi, lamanya gejala muncul dan sejauh mana gejala mengganggu fungsi biasa wanita itu relevan. Pertimbangan ini jarang dibahas dalam ukuran laporan diri. Untuk mengatasi beberapa masalah ini, skala penilaian telah dikembangkan secara khusus untuk digunakan dalam populasi pascakelahiran. Yang paling mapan adalah Edinburgh Postnatal Depression Rating Scale (EPDS). EDPS ini terdiri dari 10 item ukuran self-rated untuk mengukur kondisi depresi seorang wanita. Skala pengukuran EDPS ini telah diterjemahkan ke lebih dari dua belas bahasa dan sangat berkorelasi dengan ukuran depresi yang dinilai dokter (Cox, Holden, \& Sagovsky, 1987) [7]

\section{Tabel 1 Gangguan Afektif \\ Pascapersalinan: Ringkasan Onset, Durasi \& Perawatan}

\begin{tabular}{|c|c|c|c|c|}
\hline $\begin{array}{l}\text { Gangg } \\
\text { uan } \\
\text { Afektif }\end{array}$ & $\begin{array}{l}\text { Prev } \\
\text { alensi }\end{array}$ & Onset & $\begin{array}{l}\text { Dur } \\
\text { asi }\end{array}$ & $\begin{array}{l}\text { perawa } \\
\text { tan }\end{array}$ \\
\hline $\begin{array}{l}\text { Post } \\
\text { partum } \\
\text { blues }\end{array}$ & $\begin{array}{l}30- \\
75 \%\end{array}$ & $\begin{array}{l}\text { Hari ke } \\
3 \text { atau } 4\end{array}$ & $\begin{array}{l}\text { Jam } \\
\text { ke } \\
\text { hari }\end{array}$ & $\begin{array}{l}\text { Tidak } \\
\text { ada } \\
\text { perawat } \\
\text { an } \\
\text { khusus, } \\
\text { berikan } \\
\text { ketenan } \\
\text { gan } \\
\text { pada } \\
\text { ibu }\end{array}$ \\
\hline $\begin{array}{l}\text { Depresi } \\
\text { postpar } \\
\text { tum }\end{array}$ & $\begin{array}{l}10- \\
15 \%\end{array}$ & $\begin{array}{l}\text { Dalam } \\
12 \\
\text { bulan }\end{array}$ & $\begin{array}{l}\text { Ming } \\
\text { gu } \\
\text { ke } \\
\text { bula } \\
\mathrm{n}\end{array}$ & $\begin{array}{l}\text { Perlu } \\
\text { perawat } \\
\text { an }\end{array}$ \\
\hline $\begin{array}{l}\text { Psikosi } \\
\text { s }\end{array}$ & $\begin{array}{l}0.1- \\
0.2 \%\end{array}$ & $\begin{array}{l}\text { Dalam } \\
2 \\
\text { minggu }\end{array}$ & $\begin{array}{l}\text { Ming } \\
\text { gu } \\
\text { ke } \\
\text { bula } \\
\mathrm{n}\end{array}$ & $\begin{array}{l}\text { Perlu } \\
\text { dilakuk } \\
\text { an } \\
\text { rawat } \\
\text { inap }\end{array}$ \\
\hline
\end{tabular}

Secara historis beberapa jenis cara penilaian telah dilakukan untuk mengukur kejadian depresi. Namun untuk studi terbaru menggunakan ukuran standar dinilai dengan wawancara klinis dan atau laporan diri [7] Wawancara klinis semi terstruktur berdasarkan kriteria penelitian diagnostik memungkinkan timbulnya gejala psikopatologis untuk menegakkan diagnosis. Penggunaan wawancara standar meningkatkan keandalan diagnosis antara peneliti, dan memungkinkan peneliti untuk menetapkan dan menilai keparahan gejala, melalui pertanyaan menyelidik [7]. 


\section{Faktor Resiko}

Studi yang telah dilakukan oleh O'Hara and Swain (ibid) yang telah diterbitkan dalam jurnal peer-review adalah sebagai berikut:

Tabel 2 Faktor resiko depresi postpartum Menurut O'Hara and Swain (2009)

\begin{tabular}{|c|c|}
\hline Variabel resiko & $\begin{array}{l}\text { Tingkat signifikasi } \\
\text { efek }\end{array}$ \\
\hline \multicolumn{2}{|l|}{ Faktor klinik } \\
\hline Depresi selama kehamilan & Kuat \\
\hline $\begin{array}{l}\text { Kecemasan sebelum } \\
\text { kelahiran }\end{array}$ & Sedang \\
\hline $\begin{array}{l}\text { Riwayat depresi } \\
\text { sebelumnya }\end{array}$ & Sedang \\
\hline Riwayat depresi keluarga & Tidak ada asosiasi \\
\hline $\begin{array}{l}\text { Faktor terkait obstetri } \\
\text { dan bayi }\end{array}$ & \\
\hline $\begin{array}{l}\text { Komplikasi kebidanan } \\
\text { dan kehamilan }\end{array}$ & Lemah \\
\hline \multicolumn{2}{|l|}{ Faktor psikologi } \\
\hline Atribusi kognisi & Lemah \\
\hline neurotisisme & Sedang \\
\hline \multicolumn{2}{|l|}{ Faktor sosial } \\
\hline Pengalaman hidup & Sedang \\
\hline Dukungan sosial & Sedang \\
\hline Status perkawinan & Tidak ada asosiasi \\
\hline Hubungan perkawinan & Lemah \\
\hline Pendapatan & Lemah \\
\hline
\end{tabular}

Sedangkan studi yang dilakukan Beck (2001) terkait faktor resiko deperesi postpartum adalah sebagai berikut:

Tabel 3 Faktor resiko depresi postpartum Menurut Beck (2001)

\begin{tabular}{ll}
\hline Variabel resiko & $\begin{array}{l}\text { Tingkat } \\
\text { signifikasi efek }\end{array}$ \\
\hline Faktor klinik & \\
$\begin{array}{l}\text { Depresi selama kehamilan } \\
\text { Kecemasan sebelum }\end{array}$ & $\begin{array}{l}\text { Sedang } \\
\text { kelahiran }\end{array}$ \\
$\begin{array}{l}\text { Maternity blues } \\
\text { Riwayat depresi sebelumnya }\end{array}$ & Lemah \\
$\begin{array}{l}\text { Faktor terkait obstetri dan } \\
\text { bayi } \\
\text { Kehamilan yang tidak }\end{array}$ & \\
\hline
\end{tabular}

\begin{tabular}{ll}
\hline direncanakan & \\
$\begin{array}{l}\text { Stress pengasuhan anak } \\
\text { Temperamen anak } \\
\text { Faktor psikologi }\end{array}$ & Sedang \\
Harga diri & Sedang \\
Faktor sosial & Sedang \\
Tekanan hidup & \\
Dukungan sosial & Sedang \\
Status perkawinan & Sedang \\
Hubungan perkawinan & lemah \\
Sosialekonomi & Sedang \\
\hline
\end{tabular}

\section{METODE}

Penelitian ini bersifat analitik korelasional dengan desain cross-sectional yaitu penelitian atau penelaah hubungan antara dua variabel pada satu kesatuan atau sekelompok subyek. Penelitian ini bertujuan untuk melihat hubungan variabel independent (Kehamilan yang direncanakan, dukungan keluarga saat persalinan, komplikasi saat persalinan, pendidikan kesehatan setelah persalinan, dan keterlibatan keluarga dalam mengurus bayi) dengan variable dependen (kejadian postpartum blues)

Tempat penelitian dilaksanakan yaitu di wilayah kerja Puskesmas Tembilahan Hulu dan Puskesmas Gajah Mada pada bulan Maret sampai April 2021

Populasi adalah keseluruhan subjek penelitian. Populasi dalam penelitian ini adalah Ibu post partum hari pertama sampai tujuh hari.

Sampel adalah sebagian dari populasi yang karakteristiknya dapat menggambarkan populasi (Suryono, 2010). Purposive sampling digunakan sebagai Teknik pengambilan sampel yaitu, suatu teknik penetapan sampel dengan cara memilih sampel diantara populasi sesuai dengan yang dikehendaki peneliti (tujuan/ masalah dalam penelitian) (Nursalam, 2013). Jumlah sampel dihitung dengan menggunakan rumus besar sampel estimasi proporsi untuk simpangan mutlak sebagai berikut :

$$
n=\frac{z_{1-\alpha / 2}^{2} P(1-P)}{d^{2}}
$$


Keterangan :

$\mathrm{P}=$ Estimasi proporsi $(95 \%$ berdasarkan data proporsi cakupan persalinan fasyankes di Puskesmas Tembilahan Hulu dan Puskesmas Gajah Mada

$\mathrm{d}=$ Simpangan mutlak pada derajat kepercayaan $95 \%=0,05$

$\mathrm{z}=$ Nilai $\mathrm{z}$ pada derajat kepercayaan $1-\alpha / 2=$ 1,96

Jadi jumlah sampel adalah 73 ibu postpartum hari pertama sampai ketujuh.

Penelitian ini menggunakan data primer yaitu data yang didapatkan langsung dari pasien pada saat pasien masih di rawat di puskesmas dan saat kunjungan nifas (KF) dengan melibatkan empat orang observer dan pewawancara yang sudah dilatih. Untuk mendapatkan data tentang kejadian postpartum blues digunakan instrumen kuesioner EPDS (Edinburgh Postnatal Depression Scale).

EPDS merupakan alat ukur yang sudah diteliti dan dikembangkan untuk mendeteksi intensitas perubahan perasaan depresi selama 7 (tujuh) hari postpartum. Efektivitas instrument EPDS juga pernah diteliti oleh Latifah \& Hartati (2006), yaitu dengan membandingkan efektifitas skala EPDS dengan skala BDI (Beck Depression Inventory). Hasilnya instrument EPDS cukup efektif digunakan untuk menilai kejadian postpartum depresi sementara BDI lebih sesuai digunakan untuk menilai kasus depresi secara umum [13]

Sedangkan untuk mengamati sikap dan perilaku ibu postpartum, keluarga dan tenaga kesehatan (faktor resiko kejadian postpartum blues) didapatkan dengan menggunakan lembar checklist.

Analisis data dilakukan secara univariat dan bivariat. Untuk mengetahui korelasi variabel independen terhadap variabel dependen menggunakan uji statistik ChiSquare (X2).

\section{HASIL DAN PEMBAHASAN \\ ANALISA UNIVARIAT}

\section{Karakteristik Responden}

Tabel 4 Distribusi frekuensi karakteristik Ibu postpartum $(n=73)$

\begin{tabular}{lcc}
\hline Variabel & f & \% \\
\hline Usia Ibu & & \\
$<20$ tahun & 2 & 2,7 \\
20-35 tahun & 53 & 72,6 \\
$>35$ tahun & 18 & 24,7 \\
$\begin{array}{l}\text { Pendidikan } \\
\text { Sekolah Dasar }\end{array}$ & 6 & 8,2 \\
$\begin{array}{l}\text { Sekolah Menengah } \\
\text { Pertama }\end{array}$ & 22 & 30,1 \\
Sekolah Mennegah & 32 & 43,8 \\
Atas & & \\
Perguruan Tinggi & 13 & 17,9 \\
Paritas & & \\
Primipara & 25 & 34,2 \\
Multipara & 45 & 61,7 \\
Grandemultipara & 3 & 4,1 \\
\hline
\end{tabular}

Tabel 1 menunjukkan bahwa sebagian besar responden berusia 20-35 tahun (72,6\%), pendidikan SMA $(43,8 \%)$, dan paritas multipara $(61,7 \%)$.

\section{Faktor Resiko Kejadian Postpartum Blues Tabel 5 Distribusi frekuensi faktor yang berhubungan dengan kejadian postpartum blues $(\mathrm{n}=73)$}

\begin{tabular}{lcc}
\hline Faktor Resiko & f & \% \\
\hline Rencana Kehamilan & & \\
Kehamilan direncanakan & 59 & 80,8 \\
$\begin{array}{l}\text { Kehamilan tidak } \\
\text { direncanakan }\end{array}$ & 14 & 19,2 \\
Komplikasi Persalinan & & \\
Normal & 18 & 24,7 \\
$\begin{array}{l}\text { Ada komplikasi } \\
\text { Pendidikan kesehatan }\end{array}$ & 55 & 75,3 \\
Setelah Persalinan & & \\
Ada & & \\
Tidak ada & 60 & 82,2 \\
Keterlibatan Keluarga & 13 & 17,8 \\
dalam mengurus bayi & & \\
Terlibat & & \\
Tidak terlibat & 62 & 84,9 \\
Kejadian Postpartum & 11 & 15,1 \\
Blues & & \\
Tidak postpartum blues & & \\
Postpartum blues & 55 & 75,3 \\
\hline
\end{tabular}


Tabel 5 memperlihatkan bahwa sebagian besar kehamilan adalah direncanakan yaitu sebanyak 59 (80,8\%), persalinan dengan komplikasi/penyulit sebanyak 55 (75,3\%), mendapatkan pendidikan kesehatan yang lengkap setelah persalinan sebanyak $60(82,2)$, keluarga terlibat dalam mengurus bayi sebanyak $62(84,9 \%)$, sedangkan ibu yang mengalami postpartum blues sebanyak 18 (247\%).

\section{ANALISA BIVARIAT}

Untuk menguji hipotesa yang telah ditetapkan dilakukan uji statistik chi square dengan hasil sebagai berikut:

\section{Rencana Kehamilan dengan postpartum blues}

Hasil analisis faktor resiko rencana kehamilan dengan kejadian postpartum blues dapat dilihat pada tabel 6 berikut:

\section{Tabel 6 Hasil Analisis Hubungan faktor resiko Rencana Kehamilan dengan postpartum blues $(\mathrm{n}=73)$}

\begin{tabular}{|c|c|c|c|c|c|c|c|c|c|}
\hline \multirow{3}{*}{ Faktor } & \multicolumn{4}{|c|}{ Postpartum Blues } & \multicolumn{2}{|c|}{ Total } & \multirow{3}{*}{$\mathbf{P}$} & \multirow{3}{*}{ CI } & \multirow{3}{*}{ OR } \\
\hline & \multicolumn{2}{|c|}{ Ya } & \multicolumn{2}{|c|}{ Tidak } & \multirow[b]{2}{*}{$\mathbf{F}$} & \multirow[b]{2}{*}{$\%$} & & & \\
\hline & $\mathbf{f}$ & $\%$ & $\mathbf{f}$ & $\%$ & & & & & \\
\hline $\begin{array}{l}\text { Rencana } \\
\text { Kehamilan }\end{array}$ & & & & & & & & & \\
\hline $\begin{array}{l}\text { Tidak } \\
\text { direncanakan }\end{array}$ & 4 & 28,6 & 10 & 71,4 & 14 & 100 & 0,736 & $\begin{array}{l}0,348 \\
-\end{array}$ & 1,286 \\
\hline Direncanakan & 14 & 23,7 & 45 & 76,3 & 59 & 100 & & 4,744 & \\
\hline
\end{tabular}

Tabel 6 memperlihatkan bahwa hasil analisis antara kehamilan yang direncanakan dengan kejadian postpartum blues diperoleh bahwa ada sebanyak $10(71,4 \%)$, ibu yang tidak merencanakan kehamilannya tidak mengalami postpartum blues. Sedangkan diantara ibu yang merencanakan kehamilannya, ada sebanyak 45 (76,3\%) yang tidak mengalami postpartum blues. Berdasarkan hasil uji statistik diperoleh nilai $\mathrm{p}$-value $=0,736$ maka dapat disimpulkan tidak ada perbedaan proporsi anatara ibu yang merencanakan kehamilannya dengan tidak merencanakan kehamilannya dengan kejadian postpartum blues (tidak ada korelasi antara rencana kehamilan dengan kejadian postpartum blues).

Hasil penelitian ini tidak sejalan dengan Beck (1996), dimana peneliti meneliti efek dari kehamilan yang tidak direncanakan atau tidak diinginkan dengan kejadian depresi postpartum. Beck memasukkan hasil dari 6 studi yang terdiri dari 1200 subjek, dan menemukan ukuran efek yang kecil. Hasil ini didukung oleh Warner et al. (1996) yang menemukan hubungan yang signifikan antara kehamilan yang tidak direncanakan dan depresi pada 6 minggu pascapersalinan dalam sampel 2375 wanita. [7]

Kehamilan merupakan serangkaian proses alamiah yang dialami seorang wanita yaitu mulai dari konsepsi sampai lahirnya janin. Sebagian besar wanita hamil merasakan peristia ini adalah kondisi yang menyenangkan, didambakan, dan diinginkan sehingga perlu adanya kesiapan fisik dan psikologis. Kehamilan yang diharapkan akan membuat seorang wanita semakin siap dalam persalinan dan menjadi ibu. Persiapan yang matang membuat ibu postpartum akan siap menghadapi masa persalinan dan pasca persalinannya tanpa adanya gangguan psikologi. Namun dalam penelitian ini, tidak terdapat korelasi antara rencana kehamilan dengan postpartum blues. Perbedaan teori dan hasil penelitian ini dapat disebabkan oleh perbedaan tempat penelitian dan pertanyaan penelitian terkait rencana kehamilan.

\section{Komplikasi persalinan dengan Kejadian Postpartum Blues}

Hasil analisis faktor resiko komplikasi persalinan dengan kejadian postpartum blues dapat dilihat pada tabel 7 berikut:

\section{Tabel 7 Hasil Analisis Hubungan factor resiko Komplikasi Persalinan dengan postpartum blues $(\mathrm{n}=73)$}

\begin{tabular}{|c|c|c|c|c|c|c|c|c|c|}
\hline \multirow{3}{*}{ Faktor } & \multicolumn{4}{|c|}{ Postpartum Blues } & \multicolumn{2}{|c|}{ Total } & \multirow{3}{*}{$\mathbf{P}$} & \multirow{3}{*}{ CI } & \multirow{3}{*}{$\begin{array}{l}\mathbf{O} \\
\mathbf{R}\end{array}$} \\
\hline & \multicolumn{2}{|c|}{ Ya } & \multicolumn{2}{|c|}{ Tidak } & \multirow[b]{2}{*}{$\mathbf{F}$} & \multirow[b]{2}{*}{$\%$} & & & \\
\hline & f & $\%$ & f & $\%$ & & & & & \\
\hline \multicolumn{10}{|c|}{$\begin{array}{l}\text { Komplikasi } \\
\text { kehamilan }\end{array}$} \\
\hline Ada & 13 & 23,6 & 42 & 76,4 & 55 & 100 & 0,969 & 0,241 & 0,8 \\
\hline Tidak ada & 5 & 27,8 & 13 & 72,2 & 18 & 100 & & $\begin{array}{l}- \\
2,684 \\
\end{array}$ & 05 \\
\hline
\end{tabular}


Hasil analisa data antara komplikasi kehamilan dengan kejadian postpartum blues

\begin{tabular}{|c|c|c|c|c|c|c|c|c|c|}
\hline \multirow{3}{*}{ Faktor } & \multicolumn{4}{|c|}{ Postpartum Blues } & \multicolumn{2}{|c|}{ Total } & \multirow{3}{*}{$\mathbf{P}$} & \multirow{3}{*}{ CI } & \multirow{3}{*}{ OR } \\
\hline & \multicolumn{2}{|c|}{$\mathbf{Y a}$} & \multicolumn{2}{|c|}{ Tidak } & \multirow[b]{2}{*}{$\mathbf{F}$} & \multirow[b]{2}{*}{$\%$} & & & \\
\hline & $\mathbf{f}$ & $\%$ & f & $\%$ & & & & & \\
\hline \multicolumn{10}{|c|}{$\begin{array}{l}\text { Pendidikan } \\
\text { kesehatan } \\
\text { setelah } \\
\text { persalinan }\end{array}$} \\
\hline Tidak ada & 9 & 69,2 & 4 & 30,8 & 13 & 100 & 0,001 & 3,225 & 12,750 \\
\hline Ada & 9 & 15,0 & 51 & 85,0 & 60 & 100 & & $\begin{array}{l}- \\
50,40\end{array}$ & \\
\hline
\end{tabular}

diperoleh bahwa ada sebanyak $42(76,4 \%)$ ibu yang mengalami komplikasi persalinan yang tidak mengalami postpartum blues. Sedangkan diantara ibu yang tidak mengalami postpartum blues ada sebanyak $13(72,2 \%)$ yang tidak mengalami postpartum blues. Hasil uji statistik diperoleh nilai $\mathrm{p}=0,969$ maka dapat disimpulkan bahwa tidak ada perbedaan proporsi antara ibu yang mengalami komplikasi persalinan dengan kejadian postpartum blues (tidak ada korelasi komplikasi persalinan dengan kejadian postpartum blues).

Penelitian ini berbeda dengan hasil analisis data yang didapatkan Komalasari (2017) dimana pada penelitiannya didapatkan nilai $\mathrm{p}$-value $=0,037$ dengan peluang $2,451 \mathrm{kali}$ ibu yang mengalami komplikasi persalinan untuk terjadi postpartum blues. Persalinan dengan penyulit dan komplikasi menjadi suatu peristiwa yang rumit dan dapat menimbulkan stress bagi seorang perempuan, selain itu adanya komplikasi tersebut dapat berpeluang menimbulkan postpartum blues (Bobak, 2005). Setyowati dan Uke Riska (2006) menjelaskan bahwa pengalaman kehamilan dan persalinan tindakan dan komplikasi merupakan faktor yang mempengaruhi terjadinya postpartum blues. [1]

Dalam penelitian ini terdapat 42 (764\%) ibu yang mengalami komplikasi persalinan yang tidak mengalami postpartum blues. Hal ini bisa dipengaruhi faktor perancu yang lain seperti adanya keterlibatan keluarga dalam mengurus bayi. Dimana diketahui persentase keterlibatan keluarga dalam mengurus bayi cukup besar yaitu $55(75,3)$.

\section{Pendidikan kesehatan Setelah Persalinan dengan Postpartum Blues}

Hasil analisis faktor resiko pendidikan kesehatan dengan kejadian postpartum blues dapat dilihat pada tabel 8 berikut:

\section{Tabel 8 Hasil Analisis Hubungan faktor resiko Pendidikan Kesehatan dengan postpartum blues $(\mathrm{n}=73)$}

Hasil analisis antara pendidikan kesehatan setelah persalinan dengan keadian postpartum blues diperoleh bahwa ada sebanyak 4 $(30,8 \%)$ ibu yang tidak mendapatkan pendidikan kesehatan setelah persalinan tidak mengalami postpartum blues. Sedangkan diantara ibu yang mendapatkan pendidikan kesehatan setelah persalinan ada sebanyak 51 (85\%) tidak mengalami postpartum blues.

Beberapa penelitian memberikan bukti bahwa intervensi perawat (tenaga kesehatan) termasuk memberikan pendidikan kesehatan dapat mencegah terjadinya depresi setelah melahirkan [14]. Penting sekali bagi tenaga kesehatan yang mendampingi ibu selama masa postpartum untuk memberikan edukasi tentang perubahan psikologis serta tanda dan karakteristik postpartum blues. Health education yang dapat disampaikan yaitu tentang perawatan setelah melahirkan dan cara merawat bayi. Diharapkan, ibu yang telah mendapat edukasi, dapat mengurangi kecemasan yang menyebabkan terjadinya postpartum blues.

\section{Keterlibatan keluarga dalam mengurus bayi dengan Postpartum Blues}

Hasil analisis faktor resiko keterlibatan keluarga dengan kejadian postpartum blues dapat dilihat pada tabel 9 berikut:

Tabel 9 Hasil Analisis Hubungan faktor
resiko Keterlibatan Keluarga dengan
postpartum blues $(\mathrm{n}=73)$


Hasil analisis antara keterlibatan keluarga dengan kejadian postpartum blues diperoleh bahwa ada sebanyak $4(36,4 \%)$ ibu yang keluarganya tidak terlibat mengurus bayi tidak mengalami postpartum blues. Sedangkan diantara ibu yang keluarganya terlibat mengurus bayi ada sebanyak 55 (753\%) tidak mengalami postpartum blues.

Penelitian ini menunjukkan hasil yang sama dengan penelitian sebelumnya dimana terdapat pengaruh dukungan keluarga dengan terjadinya postpartum blues. Bagi ibu baru merawat bayi bukanlah tugas yang mudah, diperlukan dukungan keluarga terutama suami dalam pengasuhan dan perawatan bayi, karena keputusan suami dan arahan keluarga terutama ibu sangat berpengaruh dan menjadi acuan penting bagi ibu dalam merawat bayinya sehari-hari. Ibu akan merasa sedih dan kewalahan dalam mengasuh bayinya apabila suami dan keluarga tidak memberikan dukungan terutama pada hari-hari pertama pasca melahirkan.[15]

Dukungan sosial yang merupakan faktor eksternal yang dapat mempengaruhi terajdinya postpartum. Dukungan ini dapat ditujukkan melalui respon ataupun sikap kepedulian lingkungan sekitar terhadap ibu postpartum. Dengan adanya dukungan sosial dari orangorang terdekat, ibu postpartum akan merasa sangat terbantu dalam menghadapi dan melewati hari-hari pertama pasca persalinan. Hal inilah yang dapat mencegah terjadinya postpartum blues. Hal yang bisa dilakukan adalah membantu ibu baru menyesuaikan diri secara positif dan sehat untuk peran baru, tanggung jawab, dan identitas sebagai ibu. Bersabar dan berusaha untuk memahami kondisinya. Sempatkan waktu untuk selalu ada, agar ibu merasa terdukung dan tidak memendam perasaan negatif tersebut seorang diri. Membantu ibu postpartum untuk merawat dan menjaga kesehatannya sendiri, seperti membuatkan makanan yang bergizi untuknya, membantu merawat bayi, memberikan waktu istirahat yang cukup. Perhatian, dukungan, dan kasih sayang merupakan obat terbaik bagi ibu postpartum untuk meleati masa-masa sulitnya..

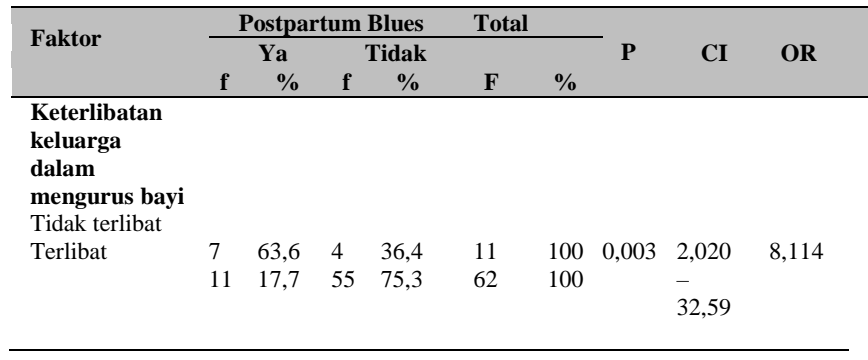

\section{KESIMPULAN}

Penelitian ini menunjukkan adanya korelasi antara pendidikan kesehatan setelah persalinan yang diberikan tenaga kesehatan $(\mathrm{p}=0,001$, CI 3,225 - 50,404, OR 12,750) dan keterlibatan keluarga dalam mengurus bayi ( $\mathrm{p}=0,003$, CI 2,020 - 32,594, OR 8,114). Sedangkan rencana kehamilan $(\mathrm{p}=0,736)$ dan komplikasi persalinan $(p=0,969)$ berdasarkan uji statistik tidak memiliki korelasi yang signifikan.

\section{DAFTAR PUSTAKA}

[1] D. Ernawati, W. O. Merlin, and I. Ismarwati, "Kejadian Postpartum Blues pada Ibu Postpartum di RS PKU Muhammadiyah Yogyakarta," J. Ners dan Kebidanan (Journal Ners Midwifery), vol. 7, no. 2, pp. 203-212, 2020.

[2] J. Roito H, N. Nurmailis, and Mardiah, Asuhan Kebidanan Ibu Nifas dan Deteksi Dini Komplikasi. EGC, 2013.

[3] A. M. Abbas, M. N. Salem, M. N. Thabet, and H. Fouly, "Factors affecting the occurrence of postpartum depression among puerperal women in Sohag city, Egypt," Proc. Obstet. Gynecol., vol. 7, no. 1, p. 4, 2017.

[4] R. Ariesca, S. Helina, and O. Vitriani, "Faktor - Faktor Yang Berhubungan Dengan Kejadian Postpartum Blues Di Klinik Pratama Wilayah Kerja Puskesmas Payung Sekaki Kota Pekanbaru," J. Prot. Kesehat., vol. 7, no. $1,2019$.

[5] R. P. Sari, A. Densy, and B. Keraman, "Analisis Faktor Risiko Kejadian Postpartum Blues Di Puskesmas Perumnas Kabupaten Rejang Lebong," J. Midwifery, vol. 8, no. 1, pp. 29-36, 
2020.

[6] A. Bener, L. M. Gerber, and J. Sheikh, "Prevalence of psychiatric disorders and associated risk factors in women during their postpartum period: A major public health problem and global comparison," Int. J. Womens. Health, vol. 4, no. 1, pp. 191-200, 2012.

[7] D. E. Stewart, E. Robertson, M. Phil, C. Dennis, S. L. Grace, and T. Wallington, "Postpartum Depression: Literature review of risk factors and interventions," WHO Publ., no. October, p. 289, 2003.

[8] C. Henshaw, "Mood disturbance in the early puerperium: a review," Arch.

Women's Ment. Heal., vol. 6, no. 2, pp. s33-s42, 2003.

[9] Yuliana, "Wellness and Healthy Magazine," Parq. los afectos. Jóvenes que cuentan, vol. 2, no. February, pp. 124-137, 2020.

[10] "Postpartum mood disorders International Review of Psychiatry_ Vol 15, No 3.”.

[11] C. Henshaw, D. Foreman, and J. Cox, "Postnatal blues: A risk factor for postnatal depression," J. Psychosom. Obstet. Gynecol., vol. 25, no. 3-4, pp. 267-272, Jan. 2004.

[12] A. N. Purwati Purwati, "Faktor- Faktor yang Menyebabkan Kejadian Postpartum Blues," vol. 10, no. 2, 2020.

[13] Machmudah, "Gangguan Psikologis Pada Ibu Postpartum; Postpartum Blues," J. Keperawatan Matern., vol. 3, no. 2, pp. 118-125, 2015.

[14] M. E. A. Budiman, S. N. J. Sari, W. Kusumawardani, and D. Sutopo, "Strategy Intervention to Prevent and Reduce Postpartum Depression: A Systematic Review," J. Ners, vol. 14, no. 3, p. 292, 2020.

[15] I. Kumalasari and H. Hendawati, "Faktor Risiko Kejadian Postpartum Blues Di Kota Palembang," JPP (Jurnal Kesehat. Poltekkes Palembang), vol. 14, no. 2, pp. 91-95, 2019. 